\title{
JOSÉ DE ALMADA NEGREIROS E O FIM DA ADIÇÃO
}

\author{
Nicolás Barbosa Lópeq'
}

Recebido: 25/10/2015

Aprovado: 01/12/2015

Resumo: Este artigo parte da quebra de códigos que simboliza da versão profana da álgebra que propõe José de Almada Negreiros. A análise concentra-se em um conjunto de aspectos centrais de A Cena do Ódio, poema que Almada Negreiros escreveu para publicar em Orpheu 3, em 1915, sob a luz da teoria que ele mesmo elucidou em um texto publicado dois anos depois, a $1^{a}$ Conferência Futurista. A análise, portanto, gira em torno das ideias da multiplicidade e da destruição, e sua manifestação ao longo de vários fios temáticos, como o ódio, o sexo e a própria linguagem.

Palavras-chave: José de Almada Negreiros, Orpheu, álgebra, futurismo, ódio

\section{JOSÉ DE ALMADA NEGREIROS AND THE END OF THE SUM}

Abstract: This article is based on the fracture of codes that symbolizes the profane version of algebra that José de Almada Negreiros proposes. The analysis is focused on a set of main aspects of A Cena do Odio [The Scene of Hate], poem that Almada Negreiros wrote in order to publish it in Orpheu 3, in 1915, in line with the theory that he elucidated in a document published two years after, $1^{a}$ Conferencia Futurista [1 $1{ }^{\text {st }}$ Futuristic Conference]. Therefore, the analysis revolves around the ideas of multiplicity and destruction, and their manifestation throughout several themes, such as hate, sex, and language itself.

Key Words: José de Almada Negreiros, Orpheu, algebra, futurism, hate.

Em uma equação matemática, são contadas as maneiras que existem para se obter 1 como resultado. Entre as mais evidentes, encontramos o resto dos números separados por uma unidade inteira de distância, ou a óbvia divisão de um número por ele mesmo. Não obstante, também há outras formas mais sofisticadas de chegar à mesma resposta, como a elevação de um número à potência 0 , que se explica a partir da lei de soma e resto exponenciais: um número $n$ elevado à potência $x$, multiplicado ou dividido por esse mesmo número $n$ elevado à potência $y$, equivale a $n$ elevado a $x+y$ (se for uma multiplicação), ou a $x-y$ (se for uma divisão). Isso quer dizer que 3 elevado a 2 dividido por 3 elevado a 2, por exemplo, é igual a 3 elevado a $2-2$, isto é, 3 elevado a 0 . E, como dissemos, um número dividido por ele mesmo é igual a 1. Concluindo: 3 elevado a 0 é igual a 1, ainda que pareça improvável que de 0 possa surgir um número positivo.

\footnotetext{
1 Literato e tradutor. Departamento de Humanidades e Literatura - Universidad de los Andes. Bogotá, Colômbia.
} 
Pode parecer estranho começar este texto referindo-me à matemática. Anteriormente, em outras publicações sobre textos de Fernando Pessoa, como O Banqueiro Anarchista, recorri aos números - e, em especial, às falácias da matemática - como metáfora da heteronímia, da quebra da lógica e da univocidade em sua obra. Este artifício retórico nunca foi uma decisão gratuita. Ali, onde Fernando Pessoa mostrava uma fascinação pela elasticidade da álgebra (ainda que em grande parte se tratasse de falácias que, eventualmente, se desmoronavam em vazios na lógica matemática), seu contemporâneo, o escritor e pintor José de Almada Negreiros, também português e colaborador de Orphen, erigiu quase a totalidade de sua obra com base em uma impossível-factível (para repetir suas palavras) equação matemática, que também alcança o 1 como resultado: $1+1=1$. Em muitos textos ao longo de sua trajetória, incluindo novelas, contos, poemas, obras de teatro, conferências e manifestos, há formulações erigidas a partir dessa lógica matemática, e uma de suas obras de teatro, intitulada Deseja-se Mulher: $1+1=1$, faz constantes alusões explícitas a essa fórmula. Ao não apresentar nenhuma soma visível, a equação parece estar conformada por elementos distorcidos que não cumprem com nenhuma função, números que não representam valores, e signos algébricos sem efeito algum.

Neste texto, partirei da quebra de códigos que simboliza esta versão profana da álgebra para analisar um conjunto de aspectos centrais de A Cena do Ódio, poema que Almada Negreiros escreveu para publicar em Orphen 3, em 1915. Farei isso sob a luz da teoria que ele mesmo elucidou em um texto publicado dois anos depois, a $1^{a}$ Conferência Futurista. Esta análise vai girar em torno das ideias da multiplicidade e da destruição, e sua manifestação ao longo de vários fios temáticos, como o ódio, o sexo e a própria linguagem.

A Cena do Ódio é, em um plano geral, uma violenta diatribe contra o homem. De entrada, o poema sugere uma ironia sobre a identidade que deixa descoberta uma preocupação em definir a pluralidade. O título vem seguido da atribuição "De José de Almada-Negreiros / Poeta sensacionista e narciso do Egipto" (ALMADA NEGREIROS, 2001, p. 23). Vemos, então, que o autor deste poema outorga uma identidade quase-trinitária: o homem do nome (de batismo) que, ao constituir a definição máxima da identidade, contém a todos; o homem de um ofício, descrito a partir de sua ocupação terrena; e o homem definido a partir de seu narcisismo, um atributo impalpável de sua personalidade. Em seguida, no poema, se encontra uma dedicatória igualmente reveladora, pois tanto o destinatário como 
a mensagem a este dedicada são intangíveis, e se sustentam sobre a ideia da multiplicidade, o primeiro por ser representante da heteronímia, e o segundo, por transmitir a ideia de reencarnação: "A Álvaro de Campos / a dedicação intensa / de todos os meus avatares" (ALMADA NEGREIROS, 2001, p. 23). Não por acaso, o adjetivo “trinitário" é apropriado para referir-se à autodenominação do poeta, posto que é ele mesmo quem prega sua identidade, seu corpo -e seu corpus- de alusões religiosas. Com estas frases introdutórias, o leitor se desloca imediatamente do Egito às religiões indo-iranianas que deram origem à ideia da reencarnação em avatares, e à medida que o poema avança se mesclam as menções ao sagrado com referências a feitiços, bruxaria e magia. Em especial, destacam-se alusões a religiões e culturas que também implicam em uma tensão de identidades múltiplas: o zoroastrismo, cujo deus Ahura Mazda representa a conjunção entre duas forças opostas -Spenta Mainyu, a força progressiva, e Angra Mainyu, a força destrutiva-; o cristianismo e seu deus tripartite; Grécia; e, por último, Egito, especialmente significativo, posto que foi precisamente de lá que fugiu o primeiro povo que proclamou a insustentabilidade do politeísmo egípcio e que, simultaneamente, cometeu um dos maiores atentados contra a multiplicidade: o surgimento do monoteismo de Israel.

O poema abre com um conjunto de versos de inverossímil execução: "Ergo-me Pederasta apupado d'imbecis / divinizo-Me Meretriz, ex-líbris do Pecado, / e odeio tudo o que não Me é por Me rirem o Eu!” (ALMADA NEGREIROS, 2001, p. 23). Vemos, portanto, um indício de que, ao longo do poema (de novo, um traço que se estende a quase toda a obra de Almada), a gramática -assim como as matemáticas e a singularidade do euserá alterada. Essa sintaxe que em princípio poderia parecer improvável, revela uma guinada, uma proposta de um novo uso da linguagem: complementos que estão a meio caminho entre o sintagma adverbial e a adjetivação ("Pederasta", "Meretriz") e que, ao mesmo tempo, ampliam as possibilidades sintáticas das palavras; ou os numerosos verbos reflexivos que, em última instância, propiciam uma redundância do $\mathrm{Eu}$, o qual parece multiplicar-se a partir de tantos sujeitos e enclíticos repetidos, mas permanecendo sempre no singular, como 1 × $1=1$.

É constante na obra de Almada o intercâmbio indistinto entre substantivos, adjetivos e advérbios e, com frequência, alguns cumprem o papel dos outros. Por esse fato, sua linguagem está inundada de neologismos e de palavras compostas nas quais se manifesta, mediante construções como "Hei-de Alfange-Mahoma" (ALMADA 
NEGREIROS, 2001, p. 23), "Silencieur do Génio-Tempestade" (ALMADA NEGREIROS, 2001, p. 26) ou "poeiro-pingo-micróbio" (ALMADA NEGREIROS, 2001, p. 35), uma supressão de preposições -sobretudo das que regem os sentidos genitivos de possessão ou pertença-, e a função simultânea de substantivos (incluindo nomes próprios e de valor sagrado como o de "Mahoma") que deixam de sê-lo para se converter, às vezes, em adjetivos, é um traço repetitivo em vários textos posteriores. Em vários deles, encontramos pares improváveis, como: "relámpago-magnésio", "gestos-cores", "trinitário bric-à-brac" (ALMADA NEGREIROS, 2001, p. 54) ou “cirius-lúmen" ALMADA NEGREIROS, 2001, p. 55) (ver Deseja-se mulher, 1928, e Mima Fataxa, 1917). Este engenho pareceria ser uma tentativa de gestar uma linguagem sucedânea mais sintética que o português original, mais mística e, por conseguinte, seletiva para ser empregada e compreendida absolutamente por poucos ou somente um: o autor mesmo. Almada alude de maneira sub-reptícia ao emparelhamento entre substantivos que adquirem funções adjetivais em Saltimbancos, um texto de 1917, publicado no único número de Portugal Futurista que, ademais, salta à vista em virtude da supressão absoluta de normas ortográficas e gramaticais:

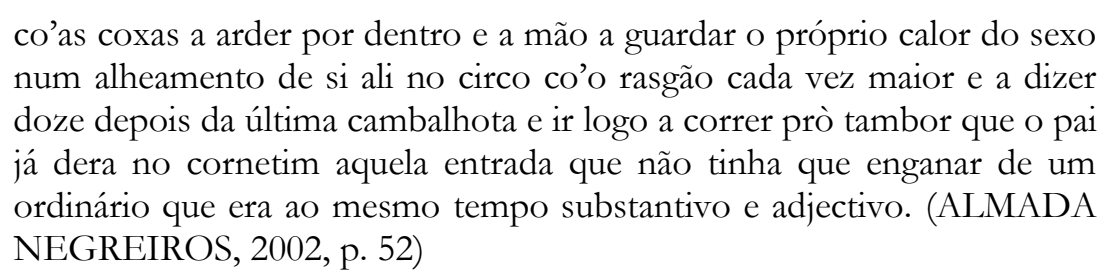

Este retorcimento linguístico põe em evidência que a informação no canal comunicativo de Almada flui, mas não avança, ou melhor, ricocheteia, em vista da ausência de interlocutores que logrem apreender a substância da mensagem. Ele nos diz em A Cena do Ódio: “Tu arreganhas os dentes quando te falam d'Orpheu / e pões-te a rir, como os pretos, sem saber porquê" (ALMADA NEGREIROS, 2001, p. 33). No entanto, a afirmação sugere que é precisamente a capacidade de criar novos códigos e destruir os anteriores - um ato representado pela figura de Orpheu- o que manifesta um pleno domínio linguístico, a diferença dos homens incapazes de compreender o enigma e de poder dar razão a suas próprias reações, e que são objeto de crítica no poema. Ou seja, é na normatividade linguística onde jaz a inconsciência, enquanto que na heteronímia o poeta alcança um nível superior das palavras. 
Da mesma forma que a alteração de códigos matemáticos na fórmula $1+1=1$, esta sintaxe tortuosa, mais que um mero assalto contra as normas estabelecidas, implica a noção (almadiana, pessoana e modernista) de que é possível flexibilizar a linguagem mediante a destruição de suas funções e de seus signos, em troca de uma superabundância de novos significantes. Trata-se, como na impossibilidade trinitária de ser pai, filho e espírito santo de uma só vez, de conferir à palavra valores aparentemente incompatíveis e excludentes entre si, mas metafisicamente simultâneos e possíveis. Outros estudiosos deste texto explicam este traço como o resultado da "palavra-acção": "A Cena do Ódio é um texto modelar de experimentalismo linguístico: valorizando maximamente a Palavra, não é apenas o Poeta que se cumpre num ser-agir; é também a sua voz que se torna gesto" (PINHEIRO e CARDOSO MENDES, 2007, p. 118).

Não só as palavras em sua forma e funções são alteradas, mas também seus significados. Em sua $1^{a}$ Conferência Futurista, Almada afirma: "Portugal, a dormir desde Camões, ainda não sabe o novo significado das palavras" (ALMADA NEGREIROS, 2004, p. 30). Tal subversão é manifesta ao longo de $A$ Cena do Ódio, começando pela noção mesma de ódio. Em primeiro lugar, o poeta diz de si mesmo: "Sou Narciso do Meu Ódio" (ALMADA NEGREIROS, 2001, p. 24), associando o narcisismo -quer dizer, o amor elevado a sua máxima potência- a sua antítese, o ódio. Este, por sua vez, poderia ser definido não somente como antipatia ou aversão, mas também como o sentimento direcionado a quem se deseja o mal, o qual é, de fato, uma forma velada de destruição. Por conseguinte, o ódio se constitui como uma metáfora do $1+1=1$, de fatores cuja soma nunca se arremata, de uma adição que sofre erosão e mingua à medida que se executa, e de uma ideia cuja essência mesma a contradiz. O poeta escreve: “O Meu Ódio é Lanterna de Diógenes / é cegueira de Diógenes, / é cegueira da Lanterna!" (ALMADA NEGREIROS, 2001, p. 24). E assim continua a cadeia de descrições impossíveis; o ódio é tanto cegueira quanto luz.

$\mathrm{Na} 1^{a}$ Conferência Futurista, o autor concede um lugar primordial ao tema do ódio e, de novo, remete o leitor a uma direção inesperada:

Portugal não tem ódios, e uma raça sem ódios é uma raça desvirilizada porque sendo o ódio o mais humano dos sentimentos é ao mesmo tempo uma consequência do domínio da vontade, portanto uma virtude consciente. O ódio é um resultado da fé e sem fé não há força. (ALMADA NEGREIROS, 2004, p. 28). 
O ódio é, portanto, como a linguagem enigmática, uma possibilidade que resulta da consciência, uma maneira de evitar a impotência, e uma virtude devido a ser um sentimento natural. Além da clara correspondência com Pessoa, que quase um ano depois, em $O$ Banqueiro Anarchista, diria que o egoísmo é uma virtude, dado que é um sentimento natural do homem (PESSOA, 2013, p. 32), essa concepção é, desta vez, uma apologia à destruição. Não somente implica que a consciência vem atrelada à destruição (pois destrói gramáticas e gesta ódios que desejam o mal), mas que também valida essa relação e a sustenta com base no oposto da destruição: a criação. O que significa que, ao ser um país sem ódios, Portugal é um impotente sexual, enquanto que o poeta, ao ser um homem viril de ódios -de destruição-, é sim um potencial reprodutor, isto é, um criador. Tal fio argumentativo é a forma como o autor justifica sua tarefa, já que sua criação poética não consiste apenas no ódio, mas também no que é possível a partir dele, que alfineta por toda parte. O que podemos ver é, então, uma poética da destruição; e no artista, um anjo exterminador.

Contudo, a diferença de Portugal, a destruição pela qual advoga o poeta redunda em uma criação: o poema. Na Conferência, Almada apresenta o contraste da destruição de Portugal que cai sobre si mesmo, sem que haja criação de tipo algum, devido à falta de consciência: "a desordem faz-se progressivamente até à putrefacção nacional. E tudo tem origem na inconsciência com que cada um existe: em Portugal toda a gente é pai pela mesma razão porque falta à repartição" (ALMADA NEGREIROS, 2004, p. 28). Isso significa que o processo de destruição não é o mesmo quando se dá sob condições de inconsciência. É no autodomínio que esse processo alcança seu nível paradoxal, sua mutação linguística, e se transforma em criação.

Assim como sua natureza múltipla lhe permite criar no ato de destruição, a criação, por sua vez, também contém o contrário, e não é uma simples superabundância de coisas somadas. No poema vemos como a esterilidade da equação $1+1=1$ se manifesta em várias figuras representativas da criação:

Olha Hugo! Olha Zola! Cervantes e Camões, / e outros que não são nada por te cantarem a ti! Olha Nietzsche! Wilde! Olha Rimbaud e Dowson! / Cesário, Anthero e outros tantos mundos! / Beethoven, Wagner e outros tantos génios / que não fizeram nada, que deixaram este mundo tal qual! (ALMADA NEGREIROS, 2001, p. 33)

Esse conjunto de criadores é desfocalizado pela sentença final de que a soma de suas criações não alcança um resultado ascendente, e enquanto equações que não logram 
ultrapassar o 1, essas criações se constituem como fatores que se cancelam entre si, como criações-destruições que não se reproduzem. Um sentido similar transmitiria Álvaro de Campos em sua Saudação a Walt Whitman, a qual também ia ser incluída em Orpheu 3, ilustrado no verso: "Eu a sensualidade curiosamente nascente até da indigência" (PESSOA, 1993, p. 24). Como afirma Alexandra Soares em sua análise sobre A Cena do Ódio: “Todo o processo de civilização implica, como Almada denuncia, a barbárie. De facto, a bestialidade associada à civilização constitui-se n'A Cena do Ódio como um dos núcleos de ataque aos fundamentos da civilização burguesa" (SOARES, 2010, p. 14).

Por sua parte, o poeta de $A$ Cena do Ódio é distinto, dado que ele é, em si mesmo, o resultado de uma destruição. Em repetidas ocasiões se identifica como o herdeiro da guerra: "Sou ruínas (...) / Sou relíquias de mártires (...) / Sou rasto espezinhado d’Invasores / que cruzaram o meu sangue" (ALMADA NEGREIROS, 2001, p. 24); e como o filho e substituto da morte: "nasci / de uma praga de ciúmes! / Eu sou as sete pragas sobre o Nilo" (ALMADA NEGREIROS, 2001, p. 25). Ao mesmo tempo em que se converte em um elo a mais na cadeia de destruições, como vítima e também algoz, e, enquanto essa humanidade que ataca é inconsciente e estéril (ou, em suas palavras, "coito d'impotentes" [ALMADA NEGREIROS, 2001, p. 26]), ele é um destruidor viril que se transborda, cuja sexualidade se constitui como metáfora última da destruição, pois, apesar de ser o único que no decorrer do poema demonstra ter uma capacidade reprodutora, ele não deixa de ser o destruidor supremo.

No centro do paradoxo está a figura da mulher, cuja função procriadora também atenta contra a criação. Por um lado, na Conferência, Almada afirma: "É preciso educar a mulher portuguesa na sua verdadeira missão de fêmea para fazer homens" (ALMADA NEGREIROS, 2004, p. 30). Por outro lado, contudo, o poema está saturado de negações filiais e de figuras femininas incapazes tanto de ser desejadas como de reproduzir-se. $\mathrm{O}$ poeta se reconhece como filho de várias destruições e nega um nascimento direto de uma mãe: “Sou (...) / órfão da Virgem do meu sentir / (...) E como queres que eu faça fortuna / se Deus, por escárnio, me deu inteligência, / e não tenho, sequer, irmãs bonitas, / nem uma mãe que se venda para mim?” (ALMADA NEGREIROS, 2001, p. 27). Ao negar a progênie, o poeta assevera sua origem, que já não pode ser outra senão a da destruição, que não é o resultado de uma procriação. Logo, imagina uma mãe hipotética, cujo único propósito é a prostituição, isto é, o sexo sem reprodução, e propicia, de novo, uma criação 
que não resulta em uma soma e que, sincronicamente, se destrói. A negação da mãe vem de mãos dadas com a censura à outra mãe -a pátria-, em torno da qual também há uma tensão que oscila entre a exaltação e o vitupério. $\mathrm{Na}$ Conferência, o autor proclama que "ama a sua pátria” (ALMADA NEGREIROS, 2004, p. 25) e que "é preciso criar a pátria portuguesa do século XX” (ALMADA NEGREIROS, 2004, p. 35), porém, ao mesmo tempo, a trata como "um país decadente" (ALMADA NEGREIROS, 2004, p. 27), e exalta que a tendência generalizada dos portugueses de falar mal de sua pátria constitui "a própria impotência física e sexual" (ALMADA NEGREIROS, 2004, p. 29). De alguma forma, então, a destruição da ascendência implica também a destruição da descendência, uma espécie de equação estanque que não se converte em nada. O poeta finaliza $A$ Cena do Ódio com um chamado compulsivo à destruição e a uma violência física que recai sobre esse "tu", os portugueses e a humanidade resumidos na segunda pessoa do singular. Esse chamado, sem embargo, conclui com uma alusão à mulher, mas desta vez como uma versão alternativa do Eu: "Hei-de ser a mulher que tu gostes, / hei-de ser Ela sem te dar atenção!" (ALMADA NEGREIROS, 2001, p. 43). O autor finaliza o poema com uma imagem do desejo insatisfeito nas mãos de uma mulher que nem sequer possibilita a procriação. Pelo contrário, o poeta se transforma em uma mulher que propicia o prolongamento da impotência e que interrompe a fruição do desejo.

O papel incerto da mulher corresponde a uma crítica geral aos papéis esperados, ao padrão estabelecido pelos homens e aos conceitos. Assim, como se alteram as matemáticas, a gramática e as noções do ódio e do sexo, também a ideia da humanidade inteira se vê capturada pela tensão. Em um texto de 1932, intitulado Direç̧ão Única, Almada terminaria de instaurar a ideia de $1+1=1$ afirmando que "Todas as coisas se relacionam entre si" (ALMADA NEGREIROS, 2004, p. 169), e que, portanto, “a mulher e o homem estão condenados à fatalidade da sua única unidade comum" (ALMADA NEGREIROS, 2004, p. 177). O que vemos ao longo de vários de seus textos, por conseguinte, são variações de uma mesma definição paradoxal da humanidade: a pluralidade que, enquanto coletividade, também é uma unidade. Na conferência Invenção do Dia Claro, de 1921, observamos a mesma ideia ampliada ao universo inteiro:

Ainda ontem o universo me parecia um gigante colossal capaz de me atropelar sem querer; e enquanto eu procurava a maneira de não ficar espezinhado pelo gigante, quem poderia, Mãe, ter-me convencido de que éramos nós-próprios o gigante? (ALMADA NEGREIROS, 2004, p. 80). 
Assim, o homem ao qual Almada insulta em seu poema parece estar destinado à impossibilidade, pois por um lado suas empresas prometeicas não somam nada e sua criação é sempre estéril: “Tu, que tens a mania das Invenções e das Descobertas / e que nunca descobriste que eras bruto, / e que nunca inventaste a maneira de o não seres..." (ALMADA NEGREIROS, 2001, p. 25); enquanto que ao mesmo tempo falha até em seu trabalho destrutivo e que, apesar de sua insignificância, não pode ser eliminado por completo, como um decimal infinito que não tem fim, nem se consome: "Agora vou esperar que morras. / Mas tu és tantos que não morres..." (ALMADA NEGREIROS, 2001, p. 27). Em consequência, o homem fracassa em seus intentos de propiciar tanto a multiplicidade quanto a unidade. Seus continentes descobertos -suas intenções de arredondar o mundo em um só- são fúteis, assim como sua independência política -seu intento de dividir-se e desmembrar-se na pluralidade-, que ao pretender fracionar o 1, uma vez mais resulta em $1+1=1$. “Ó escravos da Independência!" (ALMADA NEGREIROS, 2001, p. 28) é como, justamente, o poeta invoca essa humanidade enclausurada em um conceito ilusório da individualidade. Por sua vez, na Conferência, estende seu ataque à padronização e, como faria Fernando Pessoa pouco depois mediante uma sátira do anarquismo, Almada controverte os significados e contrapõe a igualdade à liberdade: "É preciso violentar todo o sentimento de igualdade que sob o aspecto de justiça tem paralisado tantas vontades e tantos génios, e que aparentando salvaguardar a liberdade, é a maior das injustiças e a pior das tiranias" (ALMADA NEGREIROS, 2004, p. 31).

Nesse frenesi de contradições e destruições, o poeta, veículo do ódio, se transforma em uma metáfora do incontido. Ao longo do poema, seu trabalho adquire tintas prometeicas, dado que pretende abarcá-lo todo, para unicamente logo destruí-lo como a adivinhação: “quem é o único que, quanto maior é menos se vê?”, cuja resposta não é outra que a obscuridade. Seu ódio, nos diz, é uma profusão que tudo mancha: “O Meu Ódio é Dilúvio Universal sem Arcas de Noé: só Dilúvio Universal, / e mais Universal ainda: / Sempre a crescer, sempre a subir..., / até apagar o Sol!” (ALMADA NEGREIROS, 2001, p. 24). E, paradoxalmente, ao pretender carcomer tudo, inclusive a luz, o poeta e seus ódios se transformam em nada, como o Dilúvio que, sem a Arca -sem o veículo das múltiplas criações de Deus-, não é senão um mar destruidor que nada destrói, e que, ao não ter já nada com que arrasar, somente abriga a alternativa de criar. 


\section{Bibliografia}

ALMADA NEGREIROS, José. Fiç̧ões. Assírio \& Alvim, 2002.

Manifestos e Conferências. Assírio \& Alvim, 2004.

Poemas. Lisboa: Assírio \& Alvim, 2001.

PESSOA, Fernando. El banqueiro anarquista y una entrevista sensacional. Trad. Nicolás Barbosa López. Medellín: Tragaluz, 2013.

Livro de Versos. Lisboa: Estampa, 1993.

PINHEIRO, Maria do Carmo e CARDOSO MENDES, Silva. "A Cena do Ódio: Manifesto

e Manifestação da Poética Futurista”. Diacrítica, Minho, n. ${ }^{\circ}$ 21/3, p. 93-125, 2007.

SOARES, Alexandra Paula Cerqueira. Na Linha do Fogo: A Cena do Ódio (1915), de José de Almada Negreiros. Lisboa: Universidade de Lisboa, 2010. 